ACTA MYCOLOGICA

Vol. 44 (2): 173-178

2009
Dedicated to Professor Krystyna Czyżewska

in honour of 40 years of her scientific activity

\title{
First records of Lecanora semipallida (lichenized fungi) from Romania
}

\author{
LUCYNA ŚLIWA \\ Laboratory of Lichenology, W. Szafer Institute of Botany \\ Polish Academy of Sciences, Lubicz 46, PL-31-512 Kraków, 1.sliwa@botany.pl
}

Śliwa L.: First records of Lecanora semipallida (lichenized fungi) from Romania. Acta Mycol. 44 (2): 173-178, 2009.

Lecanora semipallida is a saxicolous member of L. dispersa-group. The first localities of the species in Romania come from Southern Carpathians (Bucegi Mts.) and Eastern Carpathians (Rodnei Mts.). L. semipallida is supposed to be a common lichen species in Europe. A species of similar appearance is $L$. dispersa s.str. A key character distinguishing $L$. semipallida is the presence of epithecial granules that are soluble in $\mathrm{KOH}$. The presence of vinetorin, often causing yellowish colour of apothecia and resulting in positive spot tests and UV reactions of the apothecial disc, is also diagnostic. Apart from Romania, the species is also reported from Austria, Bulgaria, Croatia, Estonia, Hungary, Slovakia, and Ukraine.

Key words: Lecanora dispersa-group, lichen distribution, Central Europe, Balkan Peninsula

\section{INTRODUCTION}

Lecanora semipallida $\mathrm{H}$. Magn. belongs to the L. dispersa-group that is characterized by an endolithic or endophloeic, rarely superficial thallus, small apothecia with mostly white thalline margins, and either with xanthones or else lacking any secondary metabolites (Poelt et al. 1995; Fröberg 1997; Laundon 2003).

Lecanora semipallida was shown to be the correct name for the common, widespread member of the L. dispersa complex hitherto known as L. flotoviana (auct. non Spreng.). Moreover, L. xanthostoma Cl. Roux was shown to be conspecific with $L$. semipallida and therefore was relegated to synonymy (Śliwa 2007a).

A key character distinguishing L. semipallida is the presence of epithecial granules that are soluble in $\mathrm{K}$. The presence of vinetorin, often causing yellowish colour of apothecia and resulting in positive spot tests and UV reactions of the apothecial disc, is also diagnostic. Morphologically, L. semipallida is a highly variable species. The size, shape and colouration of the apothecia may vary significantly. The species 
is consistent, however, in regard to anatomy (properties of epithecial granules) and chemistry (vinetorin always present).

Lecanora semipallida is now one of the most widely distributed saxicolous species of the group, apart from L. dispersa (Pers.) Sommerf. s.str. (Śliwa 2007a, b). Most recently it has been recognized in some extra collections available at the lichen herbarium of the W. Szafer Institute of Botany, Polish Academy of Sciences in Kraków. The data are presented here.

\section{MATERIAL AND METHODS}

The study is based on recent lichen collection from Romania (by Karina Wilk, Anna and Michał Ronikier) that is housed at the KRAM-L herbarium. Some additional collections from Central Europe and Balkan Peninsula available in the herbarium as well as reference material from SOMF and Nat. Hist. Mus. were also examined for comparison.

For anatomical investigations, free-hand sections were made with a razor blade and mounted in water. Tissue measurements were made in water, and ascospore in $25 \% \mathrm{KOH}(\mathrm{K})$. Granulation of tissues was observed in polarized light. The solubility of granules or/and crystals was tested with ca $25 \% \mathrm{KOH}(\mathrm{K})$ and $65 \%$ nitric acid (N).

Chemical examination included colour reactions, response to ultraviolet light (UV) and thin-layer chromatography (TLC). Spot test reactions of thalli, apothecial margins and discs were made with $\mathrm{KOH}$ [20-30\% aqueous solution] (K), sodium hypochlorite [commercial laundry bleach] (C) and paraphenylenediamine [solution in 95\% ethyl alcohol] (PD). The TLC analyses was performed in solvent system A or C (methods followed Orange et al. 2001).

\section{RESULTS AND DISCUSSION}

Lecanora semipallida H. Magn., Lichens from Central Asia: 89. 1940.

Forms apothecia that occurr singly, or are clustered in groups, sessile, or constricted at the base to almost raised, flat when mature or flexuose, 0.4-1.3(-1.4) $\mathrm{mm}$ diam. Apothecial disc is plane, smooth, yellow, pale greenish yellow, or yelloworange to pale brown, epruinose, or slightly pruinose. Thalline margin is prominent or level with the disc, often considerably thick, smooth or rough, entire or distinctly crenate, often with bluish pigment. Thallus is immersed within the substratum, and not apparent, or crustose, indistinct to clearly visible. Occasionally pycnidia are produced on a surface of thr thallus. Pycnidia are black, inconspicuous; conidia falcate - consistently filiform and characteristically curved, 10-17(-18) $\times 1 \mu \mathrm{m}$.

Amphithecium is thick, $70-170(-270) \mu \mathrm{m}$, corticate; algae fill the area below the cortex. The cortex is usually distinctly delimited, uniform, or slightly thicker at the 
base than at the sides, $30-50 \mu \mathrm{m}$ thick laterally and $50-70 \mu \mathrm{m}$ thick at the base. It is composed of adglutinated hyphae or prosoplectenchymatous, obscured by granules occasionally interfering into the area below the cortex (prominent in polarized light, insoluble in $\mathrm{K}$, soluble in N). Parathecium is usually distinct, prosoplectenchymatous, 10-30 $\mu \mathrm{m}$ wide. Epithecium is hyaline or shades of yellow or brown, granular (prominent in polarized light). Granules are superficial and between paraphyses tips, fine to coarse, soluble in $\mathrm{K}$ and insoluble in N. Sometimes epipsamma is present (insoluble in $\mathrm{K}$, soluble in N). Hymenium is hyaline, 50-90 $\mu \mathrm{m}$ high with indistinct subhymenium. Hypothecium is also hyaline or distinctly yellow to orange (becoming more intense in K). It is composed of prosoplectenchyma and clear, without granules, confluent with parathecium and similar in colour, 50-160 $\mu \mathrm{m}$ high. Paraphyses are simple or dichotomously branched at tips, slender or thickened, not expanded, or slightly expanded apically, usually not pigmented and free in K. Asci are clavate to broadly clavate, $4-8$-spored. Ascospores are hyaline, simple, broadly ellipsoid 7.5-13 $\times 4.5-7.5 \mu \mathrm{m}$.

Apothecial margin reacts positively with some spot tests reagents $(\mathrm{K}+$ yellow, $\mathrm{C}-$ or $\mathrm{C}+$ yellow, $\mathrm{KC}+$ yellow, $\mathrm{PD}-;$ disc $\mathrm{K}+$ yellow or orange, $\mathrm{C}+$ yellow or orange, $\mathrm{PD}-$ ). The apothecia are also UV+ yellow-orange. The chemical constituent detected by TLC is vinetorin (5-chloro-3-O-methylnorlichexanthone).

In Romania L. semipallida was found on natural, calcium containing rocks and on concrete. In other parts of its range it has been found on calcareous rocks (limestone, lime-rich sandstone) as well as on concrete or overgrowing other lichens, e.g. Aspicilia calcarea (L.) Mudd, Caloplaca spp., Lecanora spp., Physcia spp., Phaeophyscia nigricans (Flörke) Moberg, Verrucaria spp.; occasionally also on bark, bryophytes and plant debris, also on metal.

Lecanora semipallida is a widespread species in Europe and North America. It occurs in the Arctic, alpine to boreal and temperate region with main distribution in temperate region. The species was also noted from Asia, Australia and New Zealand (Śliwa 2007a, b).

The most similar and likely to be confused species is $L$. dispersa s.str. from which L. semipallida differs both anatomically and chemically. Lecanora dispersa is currently recognized as having epithecial granules that often extend into part or all of the hymenium and that are $\mathrm{K}$ insoluble. The presence of pannarin in L. dispersa is also detectable in most specimens (PD+ orange, detectable especially on inner side of the apothecial margins) (Śliwa 2006). Worth mentioning is that both taxa seem to have identical distribution pattern (Śliwa 2007b).

Specimens examined. Romania. Eastern Carpathians, Rodnei Mts.: Mt. Corongiş, 47³1'36”N, 2447'39'E, vertical limestone rocks, alt. 1827 m, 30 July 2005, leg. K. Wilk 3560, 3569b (KRAM), 47³1'35'N, 2447'40”E, limestone outcrops, alt. 1812 m, leg. K. Wilk 3582b (KRAM). Southern Carpathians, Bucegi Mts.: main plateau, slopes between Cabana Babele and Muntele Caraiman, 45²4’39'N, 2528'25"E, alt. 2200 m, on calcareous rock, 26 July 2004, leg. A. Ronikier \& M. Ronikier (KRAM-L 53321); at the pass Şaua Sugărilor, 45²5'54”N, 25²7’34”E, alt. 2400 m, on calcareous rock, 27 July 2004, leg. A. Ronikier \& M. Ronikier (KRAM-L 53322).

Additional specimens examined. Austria. Wien city, Schönbrun district, near railway station, on concrete, 21 July 2005, leg. K. Wilk $3520 b$ (KRAM). Bulgaria. NE Bulgaria, the town of Shoumen: along the track to Visoka polyana, on calcareous rock, November 1970, leg. B. Zhelezova (SOMF 23477), limestone ground, on other lichens, March 1960, leg. B. Zhelezova (SOMF 24433); Osogovska Planina, along the railroad, in the surroundings of Zemen monastery, on rock, June 1952, leg. B. Zhelezova (Nat. Hist. Mus. 
2553); Pirin Mts., below Vihren peak, on limestone, 27 July 1954, leg. B. Zhelezova (Nat. Hist. Mus. 2580, as L. flotowiana!); Prov. Velingrad, Western Rodopes Mts., Beglika Nature Reserve, 15 km SSW of Batak, alt. ca $1600 \mathrm{~m}$, on calcareous rock, 27 Sept. 1975, leg. J. Nowak (KRAM-L 30322). CroATIA. Benkovac town, NE of Biograd, walls of old castle, 25 July 2007, leg. L. Śliwa 3880 (KRAM). EstoniA. Harjumaa, Lahemaa National Park, Kuusalu comm., Hundikangrud, $59.49735^{\circ} \mathrm{N}, 25.51195^{\circ} \mathrm{E}$, on limestone, 2 Aug. 2008, leg. A. Suija 106 (TU, KRAM); Tartu Co., Tõrvandi, Aia str. 50, 58.33222 N, 26.69944 E, on concrete, 18 Jan. 2009, leg. I. Jüriado (TU 45029, 45030, KRAM). HungarY. Siófok, Sóstó, Lake Balaton, Baross Gábor utca, 46 56’22.6”N, 1807’44.6”E, on concrete, 10 Jan. 2009, leg. L. Lökös (BP, KRAM). SlovaKia. Tatry Mts., Tichá dolina valley, concrete fence, 10 Aug. 2005, leg. L. Śliwa 3512 (KRAM). UKRAINE. Lviv region, Zolochiv district, Holohory, Hora in Plugowo near Plugovo village, xerothermic vegetation $10 \mathrm{~km}$ SE of Zolochiv, on calcareous rock, 4944'55”N, 2501'32”E, alt. $291 \mathrm{~m}, 23$ June 2003, leg. L. Śliwa 1840, 1855 (KRAM).

\section{CONCLUSION}

Lecanora semipallida it is one of the more distinct species of the group and most widespread, especially in temperete region of Europe and North America.

The species was reported from many countries as L. xanthostoma, e.g., Clauzade and Roux (1985), Nimis (1993), Pišút et al. (1996), Llimona and Hladun (2001), Bielczyk et al. (2005) and Lisická (2005). Most likely it was also recorded under the name L. flotov[w]iana, e.g., John (1996), Diederich and Sérusiaux (2000), Dolnik and Petrenko (2003), Clerc (2004) and Mayrhofer et al. (2005). In the latter case, however, any renaming of specimens should be made only after their thorough and critical re-determination since the name L. flotoviana has been found to have been applied to a range of different species. Full details on the status and application of the above names are provided in Śliwa (2007a). A key applicable to all species of the L. dispersa complex identification is included in the recent revision of the complex in North America (Śliwa 2007a).

Acknowledgements. Dr. Karina Wilk, Dr. Anna Ronikier and Dr. Michał Ronikier (Kraków) are thanked for making their collection available for study. Sincere thanks are due to Dr. Dimitar Stoykov (Sofia) for the loan of specimens from SOMF and Nat. Hist. Mus., as well to Inga Jüriado (Tartu)and Dr. Laszlo Lőkös(Budapest) for providing the reference material. I am indebted to Prof. dr hab. Krystyna Czyżewska (Łódź) for comments on a paper proposal. I am also grateful to the anonymous reviewer for valuable suggestions on the manuscript. The study was supported by the Ministry of Science and Higher Education, grant no. N304 050322318.

\section{REFERENCES}

Bielczyk U., Bylińska E., Czarnota P., Czyżewska K., Guzow-Krzemińska B., Hachułka M., Kiszka J., Kowalewska A., Krzewicka B., Kukwa M., Leśniański G., Śliwa L., Zalewska A. 2005. Contribution to the knowledge of lichens and lichenicolous fungi of Western Ukraine. Polish Bot. J. 50 (1): 39-64.

Clauzade G., Roux C. 1985. Likenoj de okcidenta Eŭropo. Ilustrita Determinlibro. Bull. Soc. Bot. Centre-Ouest, Numero Special 7. Royan, France, 893 pp.

Clerc Ph. 2004. Les champignons lichenisés de Suisse. Cryptog. Helv. 19: 1-314.

Diederich P., Sérusiaux E. 2000. The lichens and lichenicolous fungi of Belgium and Luxembourg. An annotated checklist. Musée national d'histoire naturelle, Luxembourg, 208 pp. 
Dolnik Ch., Petrenko D. E. 2003. Lichens of the Southern Curonian Spit in the Baltic Sea. Bot. Zhurn. 88 (2): 41-59.

Fröberg L. 1997. Variation in the Lecanora dispersa group in South Sweden. Symb. Bot. Upsal. 32 (1): 29-34.

John V. 1996. Preliminary catalogue of lichenized and lichenicolous fungi of Mediterranean Turkey. Bocconea 6: 173-216.

Laundon J. R. 2003. The status of Lecanora zosterae in the British Isles. Lichenologist 35 (2): 97-100.

Lisická E. 2005. The lichens of the Tatry Mountains. VEDA the Publishing House of the Slovak Academy of Sciences, Bratislava, $439 \mathrm{pp}$.

Llimona X., Hladun N. L. 2001. Checklist of the lichens and lichenicolous fungi of the Iberian Peninsula and Balearic Islands. Bocconea 14: 5-581.

Mayrhofer H., Denchev C. M., Stoykov D. Y., Nikolova S. O. 2005. Catalogue of the lichenized and lichenicolous fungi in Bulgaria. Mycologia Balcanica 2 (1): 3-61.

Nimis P. L. 1993. The lichens of Italy. An annotated catalogue. Museo Regionale di Scienze Naturali, Monografie 12, Torino, $897 \mathrm{pp}$.

Orange A., James P. W., White F. J. 2001. Microchemical methods for the identification of lichens. British Lichen Society, London, $101 \mathrm{pp}$.

Pišút I., Lackovičová A., Lisická E. 1996. A second checklist and bibliography of Slovak lichens. Biologia, Bratislava 51. Supplement 3: 1-79.

Poelt J., Leuckert C., Roux C. 1995. Die Arten der Lecanora dispersa-Gruppe (Lichenes, Lecanoraceae) auf kalkreichen Gesteinen im Bereich der Ostalpen - eine Vorstudie. Biblioth. Lichenol. 58: 289333.

Śliwa L. 2006. The typification of Lecanora dispersa and L. albescens. Mycotaxon 97: 291-297.

Śliwa L. 2007a. Lecanora semipallida, the correct name for L.xanthostoma, and a reappraisal of L. flotoviana (Lecanoraceae, Ascomycotina). Polish Bot. J. 52 (1): 71-79.

Śliwa L. 2007b. A revision of Lecanora dispersa complex in North America. Polish Bot. J. 52 (1): 1-70.

Pierwsze notowanie Lecanora semipallida (grzyby zlichenizowane) z Rumunii

\section{Streszczenie}

Lecanora semipallida $\mathrm{H}$. Magn. należy do naskalnych porostów z grupy L. dispersa, która charakteryzuje się plechą wgłębioną w podłoże oraz drobnymi apotecjami z białym brzeżkiem plechowym. Gatunki w tej grupie nie wytwarzają substancji porostowych lub wytwarzają ksantony. L. semipallida jest właściwą nazwą dla rozpowszechnionego taksonu z tej grupy dotąd znanego jako L. flotoviana (auct. non Spreng.). Niedawno wykazano, że L. semipallida jest identyczna z L. xanthostoma $\mathrm{Cl}$. Roux i dlatego ten ostatni gatunek uznano za synonim (Śliwa 2007a).

Lecanora semipallida jest obecnie gatunkiem najczęściej wyróżnianym w swojej grupie, choć w wielu krajach nie został on dotąd podany. Ostatnio stwierdzono go w kilku kolekcjach, które dostępne są w zielniku KRAM-L. Na podstawie zbiorów porostów z Rumunii zebranych przez Karinę Wilk oraz Annę i Michała Ronikier w niniejszej pracy L. semipallida odnotowana jest jako nowy gatunek dla tego terenu. Podano również stanowiska tego gatunku z Austrii, Bułgarii, Chorwacji, Estonii, Słowacji, Ukrainy i Węgier.

Kluczowe cechy wyróżniające $L$. semipallida to: obecność granul w epithecium, które są rozpuszczalne w K i obecność winetoryny, która powoduje żółtawy wygląd apotecjów, barwną ich reakcję na standardowe odczynniki $(\mathrm{C}+, \mathrm{K}+$ żółte lub pomarańczowe) oraz świecenie w UV. Gatunek ten występuje na skałach wapiennych, jak również na cemencie i na zaprawie murarskiej. Często osiedla się także na innych porostach, np. na Aspicilia calcarea (L.) Mudd, 
Caloplaca spp., Lecanora spp., Physcia spp., Phaeophyscia nigricans (Flörke) Moberg i Verrucaria spp. oraz wyjątkowo również na korze drzew, mszakach i szczątkach roślin, a także na metalu. L. semipallida to gatunek rozpowszechniony na świecie. Występuje często w Ameryce Północnej i w Europie; zarówno w strefie arktycznej, alpejskiej, borealnej jak i umiarkowanej.

Gatunek ten najczęściej jest mylony z L. dispersa s.str. Taksony te różnią się jednak anatomicznie i chemicznie. L. dispersa można rozpoznać dzięki granulom w epithecium, które często przechodzą do hymenium i są nierozpuszczalne w K. U większości okazów L. dispersa można również wykryć pannarynę, która powoduje reakcję pozytywną z PD (PD+ pomarańczowe). Warto podkreślić, że oba gatunki wykazują podobny wzorzec rozmieszczenia. 